\title{
UHT TREATMENT OF LIQUID EGG YOLK
}

\author{
Emna Ayari ${ }^{1}$, Csaba Németh ${ }^{2}$, Adrienn Tóth ${ }^{1}$, NoOri Khabat ${ }^{1}$, Richàrd Pintér ${ }^{1}$, \\ LÁSZLÓ FRIEDRICH ${ }^{1}$
}

${ }^{1}$ Department of Refrigeration and Livestock Products Technology, Faculty of Food Science, Szent Istvan University, Budapest, Hungary

${ }^{2}$ Capriovus Ltd., Szigetcsép, Dunasor, 073/72. hrsz., 2317 Hungary

ayari.mna@gmail.com

\begin{abstract}
Egg and its product are easily perishable items because of their high moisture content, although they have a very high amount of nutrients, especially protein. Many efforts have been channelled to increase the shelf-life of these products but heat treatment according to literature is the most promising although egg and its products are heat-sensitive. Thus, a very low temperature is needed or a high temperature for a very short time. Ultra-Heat Treatment (UHT) is one of the known technologies that we used for heat-sensitive products. The aim of the study was to investigate the effect of UHT treatment (approximately $67{ }^{\circ} \mathrm{C}$ for 190 seconds) on Liquid Egg Yolk (LEY) and Liquid Egg Yolk with additive (LEYA). During twenty-one days, the $\mathrm{pH}$ and colour were measured every seven days for all the samples. Emulsion stability was also studied by the methods of heat stability for mayonnaise. $\mathrm{pH}$ and colour measurements were used assess the quality of liquid egg yolks after 21 days of storage. From the results, raw LEY had the shortest shelf life and gave off a foul smell after 14 days of storage with significant colour changes. Addition of citric acid as an additive however improved the shelf life of the LEY with a relatively low pH. UHT treated LEY also showed improved shelf life of the LEY with a relatively constant $\mathrm{pH}$ from day 14 until the end of the experiment (day 21). UHT treatment of LEY with addition of addition of citric acid as an additive may help optimise the shelf life of the product.
\end{abstract}

Keywords: UHT, egg yolk, additive

\section{INTRODUCTION}

Egg products are becoming increasingly popular in food service operation due to convenience of use due to its tendency to save labor, storage, and portion control (Shahbaz et al., 2018). In the egg industry, microbiological safety of liquid products is mainly guaranteed by pasteurization (LECHEVALIER ET AL., 2017). Other methods of pasteurization may be approved when they give equivalent effects to those specified above as the UltraHeat treatment (UHT) which require the use of high temperature for a short time (WU, 2014). Intensive heat treatments have been reported to alter the physical and functional properties of eggs by inducing formation or destruction of covalent bonds. This, promotes changes in egg quality as a result of severe thermal protein denaturation (DAWSON AND MARTINEZ-DAWSON, 1998; LLAVE ET AL., 2018). As known, hen's yolk is an important ingredient of a wide variety of food products (BLUME ET AL., 2015). The major applications of egg yolk correspond to the manufacture and stabilization of food emulsions (mayonnaise and salad dressing), foams (bakery products) and gels (custard and caramel custard) (CORDOBÉS ET AL., 2004). Mayonnaise is probably one of the most widely used sauces or condiments in the world today; because of its low $\mathrm{pH}$ and high fat content it is relatively resistant to microbial spoilage (DEPREE AND SAVAGE, 2001). Egg yolk is a key ingredient because of its high emulsifying capacity which is related to the phospholipids, lipoproteins (LDL and HDL), and non-associated proteins (livetin and phosvitin) (MOROS ET AL., 2002; ANTON ET AL., 2007; LACA ET AL., 2010; GHAZAEI ET AL., 2015). However, in thermally treated products such as pasteurized egg liquid yolk, gel network formation can 
104

Review on Agriculture and Rural Development 2018 vol. 7 (1-2) ISSN 2063-4803

cause unpredictable structure changes through protein denaturation because egg yolk proteins are particularly thermosensitive (BLUME ET AL., 2015).

Many researchers try to reduce the thermal treatment impact on liquid egg product by adding additive.

The aim of the study was to study the effects of UHT treatment on Liquid Egg Yolk (LEY) and Liquid Egg Yolk with additive (LEYA) (approximately $67{ }^{\circ} \mathrm{C}$ for 190 seconds).

\section{MATERIAL AND METHOD}

All of the samples (liquid egg yolk (LEY)) were supplied from production line of Capriovus Ltd (Szigetcsép, Hungary) directly after treatment with UHT Tubular pasteurizer. Samples were stored at a refrigeration temperature of $5^{\circ} \mathrm{C}$ in polyethylene bags for 21 days.

The ad of the additive (citric acid) was effected before the treatment.

Colour measurements were done using the Minolta Chroma Meter CR-200, five points of the LEY bag were analysed and the average value was calculated for all samples. Colordifference $\left(\Delta \mathrm{E}^{*} \mathrm{ab}\right)$ was calculated using CIELAB system where $\mathrm{L}^{*}$ is lightness (black point $\mathrm{L}^{*}=0$, white point: $\left.\mathrm{L}^{*}=100\right)$, $\mathrm{a}^{*}$ is characteristic to red-green color $\left(+\mathrm{a}^{*}\right.$ red, $-\mathrm{a}^{*}$ green $)$, and $b^{*}$ is the blue yellow color $\left(+b^{*}\right.$ yellow, $-b^{*}$ blue).

$$
\Delta \mathrm{E}^{*} \mathrm{ab}=\sqrt{\left(\Delta \mathrm{a}^{*}\right)^{2}+\left(\Delta \mathrm{b}^{*}\right)^{2}+\left(\Delta \mathrm{L}^{*}\right)^{2}}
$$

To determinate the yolk $\mathrm{pH}$, the bags were emptied into $50 \mathrm{ml}$ beakers before measurement pre-calibrated $\mathrm{pH}$ meter (Testo 206). Three replicates per sample were taken for each of the seven days.

The mayonnaise emulsion was prepared according to the formulation described by Huang et al. 2016 but with a substitution of soybean oil for sunflower oil. The mayonnaise was composed from $1.3 \mathrm{~g}$ sugar, $0.67 \mathrm{~g}$ salt, $4 \mathrm{ml}$ vinegar, $40 \mathrm{ml}$ sunflower oil, and $10 \mathrm{~g}$ yolk.

$50 \mathrm{ml}$ from each mayonnaise sample was poured into a $100 \mathrm{ml}$ beaker and placed in a water bath with varying temperature levels of $20^{\circ} \mathrm{C}, 40^{\circ} \mathrm{C}$ and $60^{\circ} \mathrm{C}$ for 1 hour $(60$ mins). If the emulsion didn't break within this 60 minutes period, no data was recorded for time. The test was done in triplicates.

\section{RESULTS}

\section{pH}

The evolution of $\mathrm{pH}$ for the LEY throughout the conservation period is described on (Figure 1). In the beginning of study, the $\mathrm{pH}$ values of raw and UHT LEY didn't had no significant difference (7.48-7.7). While the $\mathrm{pH}$ value of UHT LEY with citric acid was approximately 5.45; this low value is explained by the addition of the citric acid.

During the 21 days of storage, the yolk $\mathrm{pH}$ was decreasing. The raw and UHT LEY $\mathrm{pH}$ considerably decreased on the first week, to an approximately $5.7 \mathrm{pH}$ level.

UHT LEYA steadily diminished to $4.95 \mathrm{pH}$ level, until the third week to some extent decrease. Despite the raw and UHT LEY preserve the same $\mathrm{pH}$ value to the end of studies. In the time using coating by beeswax, Aloe vera gel and gelatin by (MUDANNAYKA ET AL., 2016) didn't changed considerably the $\mathrm{pH}$ values during 3 weeks while the samples was stored at $30{ }^{\circ} \mathrm{C}$ without heat treatment. These results may be due because they used the whole egg. 


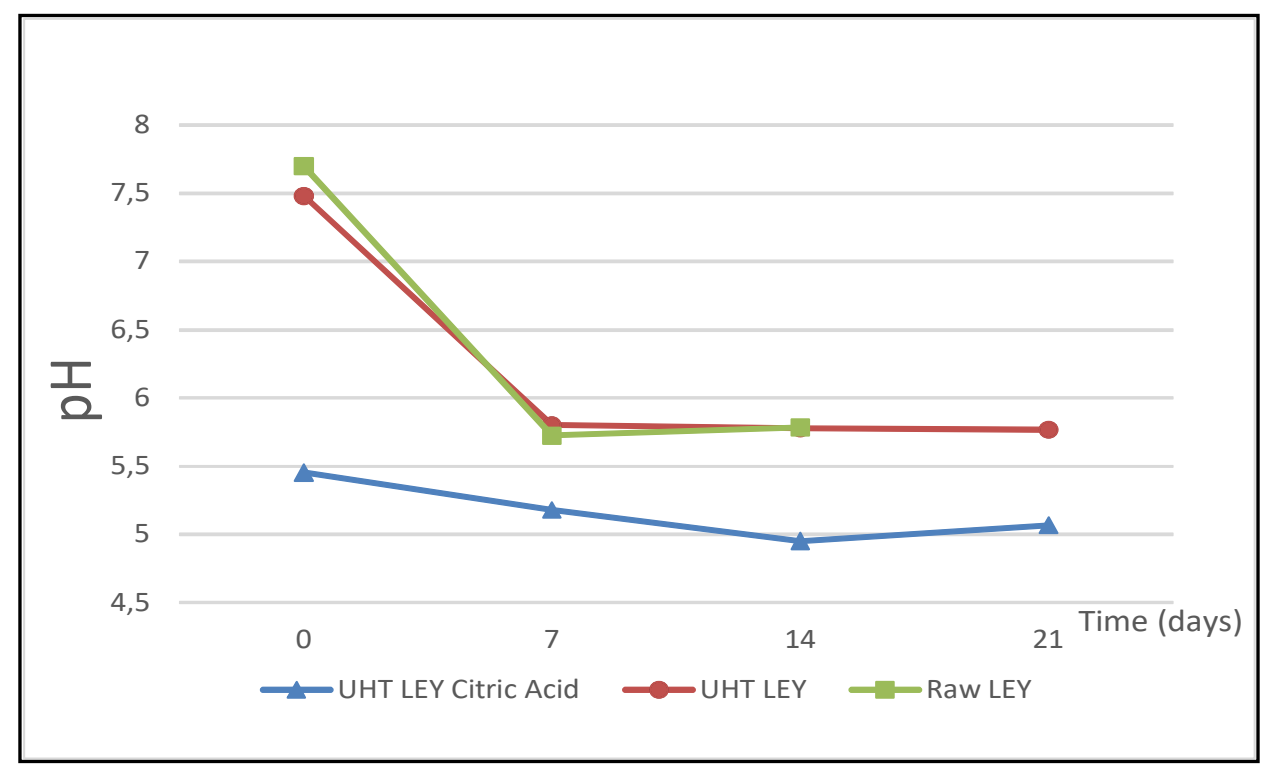

Figure 1. Evolution of pH for UHT LEY with citric acid, UHT LEY and raw LEY

From (Figure 1), raw LEY, UHT LEY and LEY with citric acid had a steady decrease in $\mathrm{pH}$ from 7.6, 7.5 and 5.5 respectively to a $\mathrm{pH}$ 7. UHT LEY with citric acid however, continued to decrease to a $\mathrm{pH}$ of 14 before rising again to $\mathrm{pH} 5$ but raw UHT and UHT LEY remained relatively constant at $\mathrm{pH} 5.8$ until the 21 days duration period of the experiment. The lower $\mathrm{pH}$ content of UHT with citric acid was attributed to the use of citric acid as an additive. Products with low $\mathrm{pH}$ are known to inhibit microbial proliferation. This suggests that UHT LEY with citric acid may be more resistant to microbial contamination compared to raw LEY and UHT LEY. UHT treatment is effective in destroying microbial presence but the ubiquitous nature of microbes exposes it to recontamination. Combining UHT treatment and citric acid as a preservative will therefore provide the best shelf-life options for LEY.

\section{Color}

Table 1. $\triangle E^{*}$ ab between UHT LEY, UHT LEY with citric and and the raw LEY

\begin{tabular}{|c|c|c|c|c|}
\hline & Day 0 & Day 7 & Day 14 & Day 21 \\
\hline Raw LEY - UHT LEY & 7.29 & 4.92 & 7.99 & 8.35 \\
\hline $\begin{array}{c}\text { Raw LEY - UHT LEY } \\
\text { with citric acid }\end{array}$ & 8.55 & 3.35 & 6.70 & 7.98 \\
\hline
\end{tabular}

$\Delta \mathrm{E}^{*} \mathrm{ab}$ allows us to compare the color between the reference which in this case is the raw LEY and the two samples which are the UHT LEY and UHT LEY with citric acid. The results are showed on (Table 1). The major color difference for the UHT LEY with additive was on the beginning of the studies where the $\Delta \mathrm{E}^{*}$ ab reach 8.55 while the UHT LEY showed the major colour difference on the last day of storage (8.35). This difference can be caused by the denaturation of egg yolk protein. As the DSC results mentioned on (CORDOBÉS ET AL., 2004) the egg yolk protein denaturation start from $60{ }^{\circ} \mathrm{C}$. However, depending on the severity of the treatment and intrinsic factors such composition and $\mathrm{pH}$, major protein can occur (VAN DER PLANCKEN ET AL., 2006). Despite the heat treatment on this study is $67^{\circ} \mathrm{C}$ for approximately 3.5 minutes probably some proteins are damaged on the treatment. 


\section{Emulsion stability}

Despite the high oil content relative to water, mayonnaise is an oil in-water emulsion (DePREE AND SAVAGE, 2001). And an oil-in-water emulsion system can be broken by the increase of temperature and oil exudation happens as a result (HUANG ET AL., 2016). Until the last day of the measurement, all the mayonnaise samples of $20^{\circ} \mathrm{C}$ didn't show any difference.

While from the beginning of the study, raw LEY mayonnaise showed an oil exudation from the first 10 minutes on both temperature $40{ }^{\circ} \mathrm{C}$ and $60{ }^{\circ} \mathrm{C}$. Both of UHT LEY and UHT LEY with citric acid mayonnaise keep their texture the whole hour on the two temperatures $40-60{ }^{\circ} \mathrm{C}$.

Starting from the first week, the UHT LEY mayonnaise started to exude oil in the end of 60 minutes at $60{ }^{\circ} \mathrm{C}$ (Figure 2). The UHT LEY with citric acid mayonnaise start to exude the oil from third weeks at $60^{\circ} \mathrm{C}$. Although, both of the mayonnaise starts to exude oil at 40 ${ }^{\circ} \mathrm{C}$ on the third weeks. On day 21 , we observe that the oil exuded on the UHT LEY with citric acid is much more than the quantity of oil exuded on UHT LEY (Figure 3).
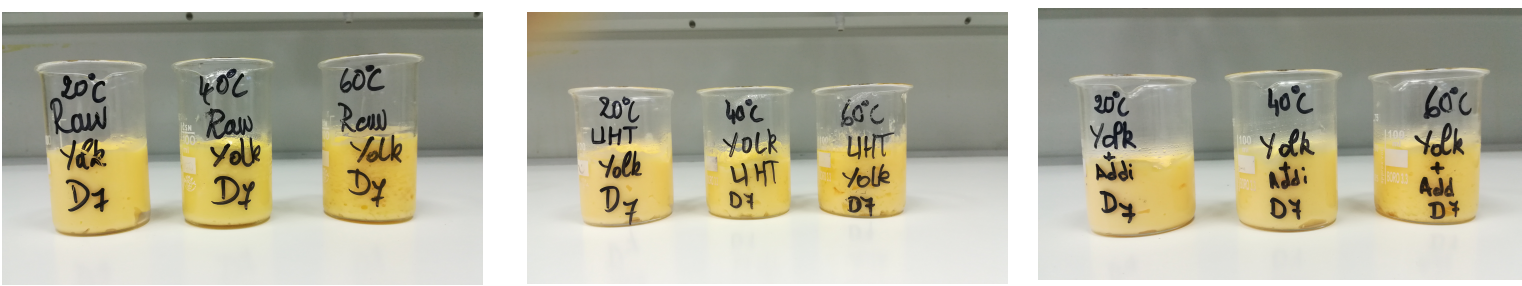

Figure 2. Heat stability of raw, UHT and UHT with citric acid LEY mayonnaise on day 7
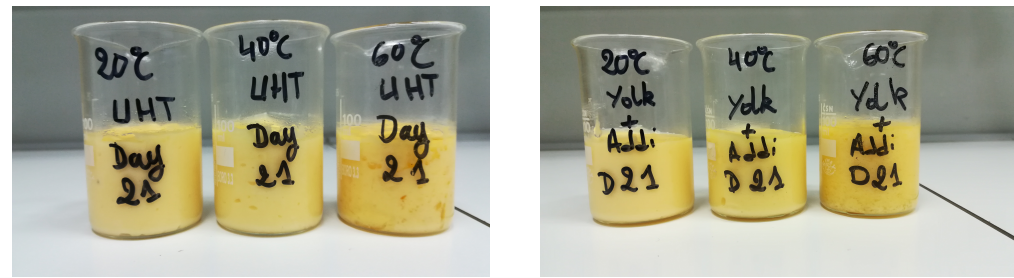

\section{Figure 3. Heat stability results of raw, UHT and UHT with citric acid LEY mayonnaise on day 21}

\section{CONCLUSIONS}

In this study, we tried to focus on the effect of UHT treatment and the addition of citric acid as an additive on the functional proprieties of liquid egg yolk. The addition of citric acid on LEY improve the heat stability of mayonnaise for the first two weeks of storage. Although, it can affect the colour of the LEY. Overall, the UHT treatment showed that it can preserve the proprieties of LEY.

\section{ACKNOWLEDGEMENTS}

We want to thank Capriovus Ltd (Szigetcsép, Hungary) for their help and for providing us with the samples we need. 


\section{REFERENCES}

Anton, M., Castellani, D., Guerin-Dubiard, C. (2007): Phosvitin. In R. Huopalahti, R. Lopez-Fandino, M. Anton \& R. Schade (Eds.), Bioactive egg yolk (pp. 17-23). Berlin, Heidelberg: Springer-Verlag.

Blume, K., Dietrich, K., Lilienthal, S., Ternes, W., Drotleff, A.M. (2015): Exploring the relationship between protein secondary structures, temperature-dependent viscosities, and technological treatments in egg yolk and LDL by FTIR and rheology. Food Chemistry 173: 584-593.

Cordobés, F., PARTAl, P., Guerrero, A. (2004): Rheology and microstructure of heatinduced egg yolk gels. Rheologica Acta 43: 184-195.

DAWson, P.L., MARTINEZ-DAWSON, R. (1998): Using response surface analysis to optimize the quality of ultrapasteurized liquid whole egg. Poultry Science 77: 468-474.

Depree, J., SAVAGe, G. (2001): Physical and flavour stability of mayonnaise. Trends in Food Science \& Technology 12: 157-163.

Ghazaei, S., Mizani, M., Piravi-Vanak, Z., Alimi, M. (2015): Particle size and cholesterol content of a mayonnaise formulated by OSA-modified potato starch. Food Sci. Technol, Campinas 35(1): 150-156.

Huang, L., Wang, T., Han, Z., Meng, Y., Lu, X. (2016): Effect of egg yolk freezing on properties of mayonnaise. Food Hydrocolloids 56, 311-317.

Laca, A., Saenz, M.C., Paredes, B., Diaz, M. (2010): Rheological properties, stability and sensory evaluation of low cholesterol mayonnaise prepared using egg yolk granules as emulsifying agent. Journal of Food Engineering 97(2): 243-252.

Lechevalier, V., Guérin-Dubiard, C., Anton, M., Beaumal, V., David Briand, E., Gillard, A., Le Gouar, Y., Musikaphun, N., Tanguy, G., Pasco, M., Dupont, D., Nau, F. (2017): Pasteurisation of liquid whole egg: Optimal heat treatments in relation to its functional, nutritional and allergenic properties. Journal of Food Engineering 195: 137149.

Llave, Y., Fukuda, S., Fukuoka, M., Shibata-Ishiwatari, N., Sakai, N. (2018): Analysis of color changes in chicken egg yolks and whites based on degree of thermal protein denaturation during ohmic heating and water bath treatment. Journal of Food Engineering 222: 151-161.

Moros, J.E., Franco, J.M., GAllegos, C. (2002): Rheological properties of cholesterolreduced, yolk-stabilized mayonnaise. Journal of the American Oil Chemists' Society 79(8): 837-843.

Mudannayaka, A.I., Wimangika Rajapaksha, D.S., Heshan Taraka KodithuwakKu, K.A. (2016): Effect of Beeswax, Gelatin and Aloe vera Gel Coatings on Physical Properties and Shelf Life of Chicken Eggs Stored at Room Temperature. J. World Poult. Res. 6(1): 06-13.

Shahbaz, H.M., Jeong, B., Kim, J.U., Ha, N., Lee, H., Ha, S.-D., Park, J. (2018): Application of high pressure processing for prevention of greenish-gray yolks and improvement of safety and shelf-life of hard-cooked peeled eggs. Innovative Food Science \& Emerging Technologies 45: 10-17.

VAN DER Plancken, I., VAN LOEY, A., HENDRICKX, M.E. (2006): Effect of heat-treatment on the physico-chemical properties of egg white proteins: A kinetic study. Journal of Food Engineering 75: 316-326.

WU, J. (2014): Eggs and egg products processing. Food Processing: Principles and Applications, Second Edition. Edited by Stephanie Clark, Stephanie Jung, and Buddhi Lamsal. 437-455 